DOI: https://doi.org/10.24127/ajpm.v10i3.3743

\title{
ANALISIS KEMAMPUAN PEMECAHAN MASALAH MATEMATIS BERMUATAN HIGHER-ORDER THINKING SKILL DITINJAU DARI GAYA BELAJAR SISWA
}

\author{
Rifda Zahra Amalia ${ }^{1}$, Windia Hadi ${ }^{2 *}$ \\ ${ }^{1,2^{*}}$ Universitas Muhammadiyah Prof Dr. Hamka, Jakarta, Indonesia \\ *Corresponding author. Cipondoh Makmur, Blok, G2/26, 15148, Banten, Indonesia \\ E-mail: riza140999@gmail.com ${ }^{1)}$ \\ windia.hadi@uhamka.ac.id $^{2 *}$
}

Received 23 May 2021; Received in revised form 09 September 2021; Accepted 01 October 2021

\begin{abstract}
Abstrak
Kemampuan pemecahan masalah matematika memiliki peran penting pada pembelajaran matematika pada kurikulum 2013 yang membuat pendidikan harus mempersiapkan generasi baru yang memiliki kemampuan berpikir tingkat tinggi dalam menyelesaikan suatu masalah. Penelitian ini bertujuan untuk mendeskripsikan kemampuan pemecahan masalah matematis bermuatan higher-order thinking skills ditinjau dari gaya belajar. Metode yang digunakan adalah deskriptif kualitatif dengan instrumen angket gaya belajar, tes tertulis dan wawancara dengan indikator kemampuan pemecahan masalah. Subyek penelitian ini adalah 36 siswa kelas 8 di kota Tangerang. Siswa diberikan angket terlebih dahulu untuk nantinya diperoleh 3 siswa secara acak melakukan tes tertulis dan wawancara. Berdasarkan hasil penelitian dapat disimpulkan kemampuan pemecahan masalah matematis bermuatan higher order thinking skills pada siswa yang memiliki gaya belajar visual mampu memenuhi dengan baik semua indikator pemecahan masalah baik dalam soal menganalisis (C4), mengevaluasi (C5), dan mencipta (C6). Siswa dengan gaya belajar auditorial mampu memenuhi semua indikator pemecahan masalah pada soal mengevaluasi (C5) dan mencipta (C6), kurang mampu dalam memenuhi indikator membuat rencana pemecahan masalah dalam soal menganalisis (C4). Dan siswa yang memiliki gaya belajar kinestetik mampu memenuhi semua indikator pemecahan masalah pada soal menganalisis (C4) dan mengevaluasi (C5), kurang mampu dalam memenuhi indikator menyelesaikan masalah dalam soal mencipta (C6).
\end{abstract}

Kata kunci: Gaya belajar; HOTS; kemampuan pemecahan masalah matematis.

\begin{abstract}
The ability to solve mathematical problems has an important role in learning mathematics in the 2013 curriculum which makes education must prepare a new generation that has high thinking skills in solving a problem. This study aims to address the problem-solving problem of higher-order thinking skills discussed in terms of learning styles. The method used is descriptive qualitative with learning style instruments, written tests and interviews with indicators of problem-solving abilities. The subjects of this study were 36 8th grade students in the city of Tangerang. Students were given a questionnaire first and then 3 randomly obtained a written test and interview. Based on the results of the study, it can unlock the problem-solving ability of higher thinking skills in students who learn visual style well all indicators of problem solving in analyzing (C4), possessing (C5), and creating (C6). Students with auditory learning style are able to overcome all problem solving indicators on questions (C5) and create (C6), less able to overcome indicators of making problem solutions in analyzing problems (C4). And students who have a kinesthetic learning style are able to meet all problem indicators on analyzing questions (C4) and skills (C5), less able to solve problems in creating (C6).
\end{abstract}

Keywords: HOTS; learning styles; mathematical problem solving ability. 
DOI: https://doi.org/10.24127/ajpm.v10i3.3743

\section{PENDAHULUAN}

Berdasarkan kurikulum 2013 peran pendidikan di Indonesia berfokus untuk mengembangkan sumber daya manusia (SDM) yang meliputi kognitif, afektif, dan psikomotorik. Dalam meningkatkan sumber daya manusia pada kurikulum 2013 pendidikan harus menyiapkan generasi baru yang memiliki kemampuan berpikir tingkat tinggi (Higher Order Thingking Skills) agar mampu berpikir secara logis, kreatif, analitis, sistematis, krisis, bekerja sama dan mampu memecahkan masalah.

Kemampuan pemecahan masalah merupakan hal yang sangat penting dikembangkan pada siswa dalam pembelajaran matematika (Ahmad, 2017; Akbar et al., 2017). Oleh karenanya, kemampuan pemecahan masalah perlu adanya pemikiran yang kompleks agar siswa dapat mengetahui cara mengatasi permasalahan yang berhubungan dengan soal HOTS matematika (Harahap \& Surya, 2017; Suratmi \& Purnami, 2017). Pada dasarnya Kemampuan pemecahan masalah dapat memudahkan siswa dalam mengetahui masalah, membuat rancangan penyelesaian masalah, menyelesaikan masalah dan menganalisis jawaban yang diperoleh (Putra et al., 2018). Selain itu diadakannya juga pembiasaan siswa dalam mengerjakan soal-soal latihan tipe HOTS agar tidak ada lagi kesulitan dalam memecahkan suatu permasalah matematika (Saputri \& Hadi, 2021).

Kemampuan pemecahan masalah dengan kemampuan berpikir tingkat tinggi dalam pembelajaran matematika di Indonesia masih sangat rendah (Amalia \& Hadi, 2020). Rendahnya kemampuan pemecahan masalah siswa dapat dilihat berdasarkan dari hasil survey PISA dan TIMSS (2018) yang diinisiasi oleh Organization for Economic Co-operation and Development (OECD) dengan tujuan untuk menguji program pendidikan secara mendunia. Pada tahun 2018 (OECD, 2019) menyatakan bahwa Indonesia hanya mendapat skor kemampuan matematika berkisar 379 yang merupakan skor di bawah ambang batas Internasional yaitu 489 serta masih dengan kedudukan peringkat 72 dari 77 negara. Selain itu dalam penelitian (Rambe \& Afri, 2020) menerangkan bahwa kemampuan pemecahan masalah matematis siswa belum optimal karena masih banyak siswa mendapati kesulitan pada merencanakan pemecahan masalah dan memeriksa kembali jawaban. Rendahnya kemampuan pemecahan masalah matematis karena kurang mampunya siswa dalam menguasai materi penunjang, menerapkan materi dan menyelesaikan masalah ke dalam bentuk nyata (Mariam et al., 2018).

Dalam proses keberhasilan memecahkan masalah seorang siswa bergantung juga pada faktor siswa itu sendiri yang dapat memperoleh dan menyerap informasi yang dipengaruhi oleh gaya belajar (Richardo et al., 2014; Solihah et al., 2020). Gaya belajar adalah identitas dalam diri setiap siswa dalam mengukir dan menampung informasi dari sekitar yaitu lingkungan belajar (Yusuf et al., 2016). Gaya belajar adalah perbedaan siswa dalam menafsirkan, memproses dan mengomunikasikan informasi dalam memecahkan masalah (Mangwende \& Maharaj, 2019).

Kemampuan pemecahan masalah seorang siswa berbeda-beda dengan taraf kecerdasan dan cara yang berbedabeda (Ilmi \& Rosyidi, 2016). Sangat penting bagi guru agar bisa mengenal gaya belajar yang dikuasi oleh setiap 
siswa. Tiap individu belajar menggunakan teknik yang bertentangan untuk menemukan maupun mengetahui isi materi pembelajaran, dan semua teknik sama baiknya. Setiap cara mempunyai antusiasme sendiri (Wahyuni, 2017). Tipe gaya belajar siswa mengutamakan suatu penentuan cara membimbing yang sejalan agar antusiasme gaya belajar siswa berkembang dengan baik. Dengan menyertakan perspektif visual, auditorial, dan kinestetik diharapkan mampu meningkatkan proses belajar.

Sementara itu, hasil penelitian (Umrana et al., 2019) gaya belajar visual, gaya belajar audiotorial dan gaya belajar kinestetik memiliki kemampuan pemecahan masalah matematis yang berbeda-beda. Kemampuan pemecahan masalah matematis pada siswa dengan gaya belajar visual yaitu mampu memenuhi semua indikator pemecahan masalah dalam memahami masalah, merencanakan penyelesaian masalah, melakukan penyelesaian masalah dan memeriksa hasil jawaban yang diperoleh dengan baik.

Kemampuan pemecahan masalah matematis pada siswa dengan gaya belajar auditorial hanya bisa mencapai dengan baik indikator melaksanakan penyelesaian masalah. Dikarenakan karakteristik siswa yang gampang terusik dengan keributan. maka siswa yang memiliki gaya belajar visual terlihat kurang fokus ketika peneliti mencoba bertanya saat mengerjakan soal. Sehingga saat memeriksa kembali jawaban harus digali berulang-ulang untuk mendapat hasil yang baik.

Kemampuan pemecahan masalah matematis pada siswa dengan gaya belajar kinestetik juga hanya bisa mencapai dengan baik indikator melaksanakan penyelesaian masalah artinya tidak mampu dalam memeriksa kembali jawaban. Karena untuk memperoleh hasil yang maksimal siswa yang dengan gaya belajar kinestetik ini harus dilaksanakan dengan waktu yang panjang dan berulang-ulang. Oleh karena itu, berdasarkan hasil penelitian yang telah dipaparkan bahwa kemampuan pemecahan masalah matematis dengan gaya belajar visual mampu memenuhi semua indikator kemampuan pemecahan masalah matematis.

Untuk itu pada penelitian sebelumnya, belum ditemukan penelitian yang menganalisis kemampuan siswa dalam memecahkan permasalahan matematis dengan gaya belajar yang berbeda-beda dengan tipe soal yang sesuai dengan kurikulum 2013 yang mengharuskan siswa untuk mempunyai kemampuan berpikir tingkat tinggi agar mampu bersaing dengan negara lainnya dalam pembelajaran matematika terutama dalam kemampuan pemecahan masalah matematis. Sehingga perlu adanya penelitian selanjutnya untuk mengetahui kemampuan pemecahan masalah matematis siswa dengan gaya belajar yang berbeda-beda pada soal dengan kemampuan berpikir tingkat tinggi. Sehingga dengan permasalahan yang ada, penelitian ini bertujuan untuk menganalisis kemampuan siswa dalam memecahkan masalah matematis dengan tipe HOTS (higher order thinking skills) berdasarkan dari gaya belajar, karena setiap siswa memiliki cara berpikir yang berbeda-beda dalam memecahkan masalah, hal ini diduga dipengaruhi oleh gaya belajarnya.

\section{METODE PENELITIAN}

Metode penelitian ini adalah metode Kualitatif deskriptif artinya penelitian ini bertujuan untuk menganalisis dan mendeskripsikan 
DOI: https://doi.org/10.24127/ajpm.v10i3.3743

gambaran mengenai kemampuan siswa dalam memecahkan masalah matematis bermuatan higher order thinking skills dilihat dari gaya belajar siswa, dimana penelitian ini menggunakan tahapan yaitu pertama peneliti melakukan pengamatan lapangan untuk mendapatkan focus masalah pada lapangan. Tahapan selanjutnya menentukan subyek penelitian yaitu 3 siswa dari 36 siswa kelas 8 semester genap tahun 2021/2022 di SMP Negeri 28 Tangerang. Untuk menentukan 3 siswa dari 36 siswa dilakukannya teknik pengumpulan data dengan pengisian angket gaya belajar (visual, audiotorial, kinestetik) pada setiap siswa dengan menggunakan google form.

Dari angket yang telah dikumpulkan akan dianalisis dengan menghitung rata-rata hasil jawaban setiap pertanyaan untuk mengetahui siswa mana yang unggul dalam setiap gaya belajar baik visual, auditorial, dan kinestetik. Kemudian pada tahap selanjutnya, dipilih secara acak 3 siswa dari setiap gaya belajar untuk untuk melakukan tes kemampuan pemecahan masalah matematis bermutan HOTS yang terdiri dari $\mathrm{C} 4, \mathrm{C} 5$ dan $\mathrm{C} 6$ dengan gaya belajar visual, auditorial dan kinestetik.

Instrumen tes kemampuan pemecahan masalah matematis bermuatan HOTS tes kemampuan pemecahan masalah matematis yang telah dinyatakan valid oleh dua dosen pendidikan matematika UHAMKA dengan catatan untuk soal C4 diperingkas kalimatnya, yaitu gunakan kalimat inti dari permasalahan sehingga memudahkan siswa dalam memahami masalah dapat dilihat pada Tabel 1 .

Tabel 1. Instrumen tes kemampuan pemecahan masalah bermuatan HOTS

\begin{tabular}{|c|c|}
\hline $\begin{array}{c}\text { Indikator } \\
\text { HOTS }\end{array}$ & Soal \\
\hline $\mathrm{C} 4$ & $\begin{array}{l}\text { Pada perayaan ulang tahun sekolah SMAN } 1 \text { Tangerang, seluruh siswa yang } \\
\text { berjumlah } 300 \text { siswa akan mengadakan acara pensi yang akan diikuti oleh } \\
\text { seluruh warga sekolah. Di dalam acara pentas seni siswa diminta untuk } \\
\text { menyiapkan penampilannya masing -masing dalam rangka meriahkan acara } \\
\text { ulang tahun sekolah baik berupa stand up comedy, musikalisasi puisi dan } \\
\text { menari tarian tradisional. Sebanyak } \frac{2}{3} \text { siswa memilih untuk menampilkan } \\
\text { tarian tradisional, sebanyak } 36 \% \text { siswa memilih menampilkan stand up } \\
\text { comedy, } \frac{1}{3} \text { siswa memilih menampilkan musikalisasi puisi dan tarian } \\
\text { tradisional, 54\% siswa memilih menampilkan musikalisasi puisi. Berapa } \\
\text { siswa yang memilih menampilkan musikalisasi puisi dan stand up comedy? }\end{array}$ \\
\hline C5 & $\begin{array}{l}\text { Pak Arya lahan bermain dan lahan berkebun di halaman rumahnya. Jika } \\
\text { lahan berkebun memiliki lebar } 2 \text { meter lebih kecil dari panjangnya dan } \\
\text { keliling lahan tersebut adalah } 16 \text { meter, sedangkan lahan bermain berukuran } \\
3 \text { kali lebih besar dari lahan berkebun. Tentukan panjang dan lebar lahan } \\
\text { apakah luas dari lahan bermain adalah } 124 \mathrm{~cm}^{2} \text { ! }\end{array}$ \\
\hline C6 & $\begin{array}{l}\text { Pak Rudi berencana akan membuat kolam ikan untuk usaha perikanan di atas } \\
\text { sebidang tanah berbentuk persegi panjang dengan ukuran } 20 \mathrm{~m} \text { dan lebar } \\
(2 \mathrm{~s}+1) \mathrm{m} \text {. Jika luas tanah pak Rudi tidak lebih dari } 180 \mathrm{~m}^{2} \text {. Tentukan: } \\
\text { a. Berapa lebar tanah pak Rudi? } \\
\text { b. Biaya maksimal untuk menggali tanah } 1 \mathrm{~m}^{2} \text { adalah Rp } 500.000,00 \text {. } \\
\text { Berapa biaya maksimal yang harus disediakan pak Rudi? }\end{array}$ \\
\hline
\end{tabular}


DOI: https://doi.org/10.24127/ajpm.v10i3.3743

Untuk memahami kemampuan pemecahan masalah matematis siswa dalam menyelesaikan soal bermuatan HOTS, data dianalisis sesuai dengan indikator dari kemampuan pemecahan masalah matematis yang meliputi : (1) memahami masalah, (2) membuat rencana pemecahan masalah, (3) memilih dan mengembangkan model pemecahan masalah, dan (4) memeriksa kembali hasil yang diperoleh.

Untuk memahami kemampuan pemecahan masalah matematis siswa dalam menyelesaikan soal bermuatan HOTS, data dianalisis sesuai dengan indikator dari kemampuan pemecahan masalah matematis yang meliputi : (1) memahami masalah, (2) membuat rencana pemecahan masalah, (3) memilih dan mengembangkan model pemecahan masalah, dan (4) memeriksa kembali hasil yang diperoleh.

Kemudian dilakukan wawancara berdasarkan gaya belajar visual, auditorial dan kinestetik dengan 3 siswa yang dipilih untuk mengerjakan tes kemampuan pemecahan masalah matematis bermuatan HOTS untuk di validasi sesuai indikator tes kemampuan pemecaham matematis agar dapat diketahui kemampuan pemecahan masalah siswa dalam menyelesaikan tes uraian bermuatan HOTS. Selanjutnya dilakukannya teknik analisis data yang digunakan dalam penelitian ini adalah triangulasi metode. Triangulasi metode adalah mengandaikan dan memeriksa kembali mutu keyakinan suatu informasi yang diperoleh melalui sumber data, waktu dan alat yang berbeda. Setelah dianalisis, pada tahap terakhir akan disusun pembahasan yang berisi deskripsi dari hasil penelitian yang diperoleh dari pengisian angket, tes tertulis kemampuan pemecahan masalah dan wawancara untuk kemudian ditarik kesimpulan dari hasil pembahasan.

\section{HASIL DAN PEMBAHASAN}

Penelitian ini menganalisis tentang kemampuan pemecahan masalah matematis siswa dalam soal bermuatan HOTS berdasarkan gaya belajar visual, auditorial, dan kinestetik. Data penelitian ini didapatkan dari pengisian angket gaya belajar, tes uraian kemampuan pemecahan masalah matematis bermuatan HOTS dan wawancara dengan siswa yang memiliki gaya belajar visual, auditorial maupun kinestetik. Selanjutnya di bawah ini akan dipaparkan hasil wawancara siswa dalam menyelesaikan tes uraian kemampuan pemecahan masalah matematis bermuatan HOTS.

\section{Paparan hasil Kemampuan pemecahan masalah matematis bermuatan HOTS ditinjau dari gaya belajar visual}

Kemampuan pemecahan masalah siswa dalam menyelesaikan masalah bermuatan HOTS berdasarkan gaya belajar visual dipilih secara random dengan inisial KN. Berdasarkan hasil jawaban, KN mampu menyelesaikan semua soal tes uraian dengan baik. hasil jawaban KN disajikan pada Gambar 1.

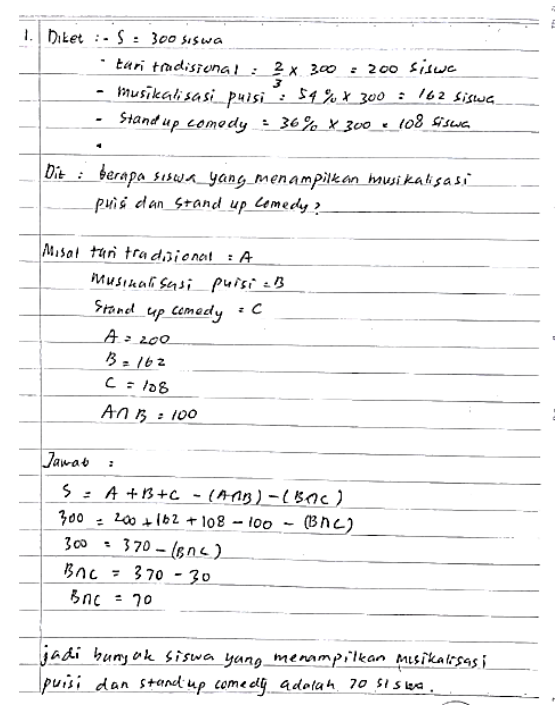

Gambar 1. Hasil jawaban KN pada soal C4. 
Adapun hasil dari wawancara Peneliti (P) dengan $\mathrm{KN}$ adalah sebagai berikut.

P : "Pada soal C4 informasi apa saja yang diketahui?"

$\mathrm{KN}$ : "Informasi yang saya dapatkan, SMAN 1 Tangerang mengadakan acara pentas seni yang diikuti oleh 300 siswa. $2 / 3$ siswa menampilkan tarian tradisional, 54\% menampilkan musikalisasi puisi, 36\% siswa menampilkan stand up comedy, $1 / 3$ menampilkan musikalisasi puisi dan tarian tradisional"

P : "Lalu bagaimana langkahlangkah kamu dalam menyelesaikan masalah C4?"

$\mathrm{KN}$ : "Langkah pertama saya misalkan terlebih dahulu untuk seluruh siswa yang mengikuti pentas seni saya misalkan dengan $\mathrm{S}$, tarian tradisional saya misalkan A, musikalisasi puisi saya misalkan $B$, stand up comedy saya misalkan $\mathrm{C}$ dan untuk siswa yang menampilkan musikalisasi puisi dan tarian tradisional saya misalkan $(A \cap B)$. Kemudian untuk menentukan banyaknya siswa yang memilih menampilkan musikalisasi puisi dan stand up comedy dimisalkan dengan $(B \cap C)$ ".

$\mathrm{P} \quad$ : "Bagaimana selanjutnya?"

$\mathrm{KN}$ : "Maka $B \cap C=200+162+$ $108-100-300=70$. Jadi banyaknya siswa yang memilih menampilkan musikalisasi puisi dan stand up comedy adalah 70 siswa."

P : "Kemudian Informasi apa yang kamu dapatkan dari soal C5?"

$\mathrm{KN}$ : "Informasi yang saya dapatkan, lahan berkebun memiliki keliling 16 meter dengan lebar
2 meter lebih kecil dari panjangnya. Lahan bermain berukuran 3 kali lebih besar dari lahan berkebun."

Berdasarkan hasil wawancara pada soal $\mathrm{C} 4 \mathrm{KN}$ mampu memenuhi semua indikator pemecahan masalah yaitu memahami masalah, menyusun rencana pemecahan masalah dalam pemecahan masalah, dan memeriksa kembali hasil jawaban. Hal ini ditunjukkan dari hasil jawaban dan wawancara $\mathrm{KN}$ yang dapat menjelaskan penyelesaian masalah dengan baik. Gambar 2 adalah reaksi tanggapan $\mathrm{KN}$ pada soal C5.

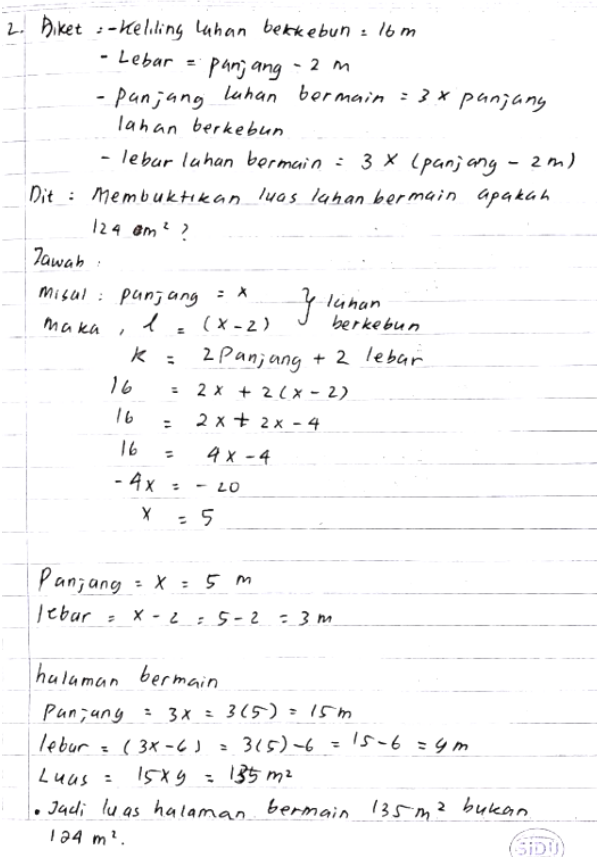

Gambar 2. Hasil jawaban KN pada soal C5.

Berikut hasil wawancara peneliti (P) dengan KN terkait soal C5.

P : "Bagaimana langkah kamu dalam menyelesaikan masalah pada soal C5?"

KN : "Langkah pertama, misalkan panjang adalah $p$ dan lebar lahan berkebun adalah $(p-2)$ 
DOI: https://doi.org/10.24127/ajpm.v10i3.3743

meter. Karena yang diketahui pada soal adalah keliling lahan berkebun, maka untuk mendapatkan nilai $K=$ 2 panjang +2 lebar. Kemudian subtitusikan panjang, lebar dan kelilingnya ke rumus, sehingga $16=2 p+2(p-2)) \rightarrow 16=$ $2 p+2 p-4 \rightarrow 16=4 p-4$. Kemudian kita hilangkan angka -4 dengan menjumlahkan 4 pada ke dua sisi $16+4=$ $4 p-4+4$ akan didapatkan $20=4 p$, maka nilai $p$ adalah $\frac{20}{4}=5 \mathrm{~m}$. Maka panjang dari lahan berkebun adalah $5 \mathrm{~m}$. Untuk lebar lahan berkebun adalah $L=$ panjang $-2=5-$ $2=3 \mathrm{~m}$.

P : "Lalu bagaiman dengan lahan bermain?"

$\mathrm{KN}$ : "Untuk lahan bermain, diketahui pada soal bahwa lahan bermain berukuran 3 kali lebih besar dari lahan berkebun, sehingga untuk panjang dan lebarnya pun 3 kali lebih besar dari lahan berkebun. Maka $p=3 x=$ $3(5)=15 \mathrm{~m} \quad$ dan $\quad l=$ $3(x-2)=3 x-6=3(5)-$ $6=15-6=9 \mathrm{~m}$. Sehingga luas lahan bermain adalah $L=p \times l=15 \times 9=135 \mathrm{~m}^{2}$. Jadi luas lahan bermain adalah $135 \mathrm{~m}^{2}$ bukan $124 \mathrm{~m}^{2}$."

Berdasarkan hasil wawancara tentang soal $\mathrm{C} 5, \mathrm{KN}$ mampu memenuhi semua indikator pemecahan masalah yaitu memahami masalah, menyusun rencana pemecahan masalah, dan memeriksa kembali hasil jawaban. Hal ini ditunjukkan dari hasil jawaban (Gambar 3) dan wawancara KN yang dapat menjelaskan penyelesaian masalah dengan baik.

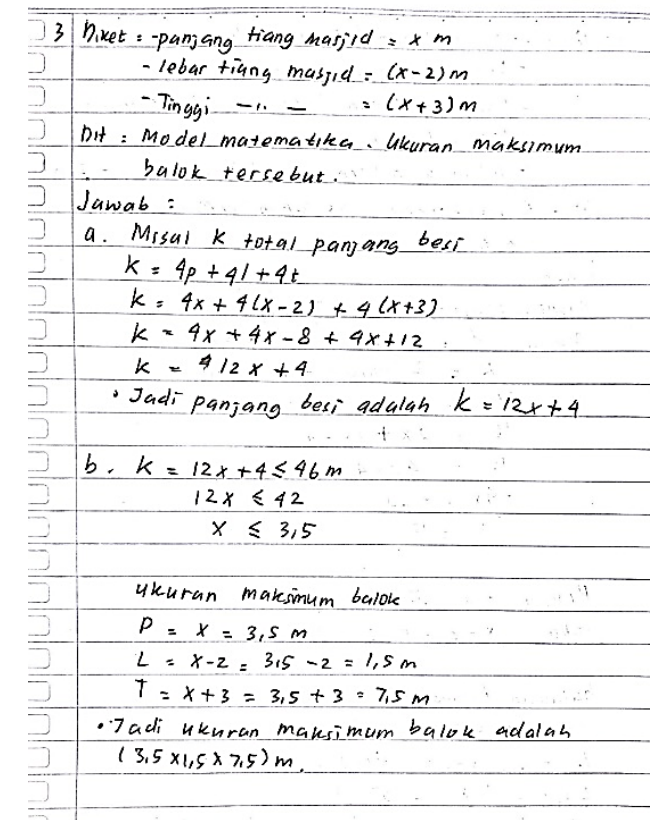

Gambar 3. Hasil jawaban KN pada soal C6.

Berikut hasil wawancara peneliti (P) dengan $\mathrm{KN}$ terkait soal C6.

P : "Selanjutnya informasi apa yang kamu dapatkan dari soal C6?"

$\mathrm{KN}$ : "Informasi yang saya peroleh dari soal C6, panjang tiang masjid $=x \mathrm{~m}$, lebar tiang masjid $=(x-2) m$, tinggi tiang masjid $=(x+3) m$.

$\mathrm{P} \quad$ : "Bagaimana langkah kamu dalam menyelesaikan masalah ini?"

$\mathrm{KN}$ : "Langkah pertama, kita dapat membuat persamaan dengan menggunakan rumus keliling balok untuk mengetahui panjang besi yaitu $K=4 p+$ $4 l+4 t$. Kemudian kita subsitusikan panjang, lebar dan tingginya ke dalam rumus, maka $K=4(x)+4(x-2)+$ $4(x+3) \quad$ sehingga $\quad K=4 x+$ $4 x-8+4 x+12=12 x+4$.

Jadi panjang besi adalah $K=12 x+4 . "$ 
DOI: https://doi.org/10.24127/ajpm.v10i3.3743

$\mathrm{P} \quad:$ :Kemudian bagaimana?"

$\mathrm{KN}$ : "Kemudian kita buat pertidaksamaannya adalah $12 x+4 \leq 46 \mathrm{~m}$, karena di dalam soal panjang besi tidak lebih dari 46. Selanjutnya kita selesaikan pertidaksamaan tersebut untuk mendapatkan nilai $x$ nya. Pertama, kita kurangkan kedua ruas dengan 4 maka akan di dapat $12 x+4-$ $4 \leq 46-4 \rightarrow 12 x \leq 42$ selanjutnya bagi kedua ruas dengan 12 sehingga $x=\frac{42}{12}=3,5$.

Kemudian subtitusikan nilai $x$ ke dalam persamaan lebar dan tingginya, maka $l=x-2=$ $3,5-2=1,5 \mathrm{~m}$ dan $t=x+$ $3=3,5+3=6,5 \mathrm{~m}$. Jadi ukuran maksimum balok adalah $(3,5 m \times 1,5 m \times 6,5)$."

Berdasarkan hasil wawancara pada soal $\mathrm{C6} \mathrm{KN}$ mampu memenuhi semua indikator pemecahan masalah yaitu memahami masalah, menyusun rencana pemecahan masalah dalam pemecahan masalah, dan memeriksa kembali hasil jawaban. Hal ini ditunjukkan dari hasil jawaban dan wawancara $\mathrm{KN}$ yang dapat menjelaskan penyelesaian masalah dengan baik.

Sejalan dengan (Imamuddin et al., 2019) yang menjelaskan bahwa visual lebih unggul dari siswa auditorial dan kinestetik dalam kemampuan pemecahan masalah matematis. Dan pada penelitian (Setyadi et al., 2020) juga mengatakan bahwa siswa yang memiliki daya belajar visual memiliki nilai ratarata lebih unggul dari siswa yang memiliki gaya belajar auditorial.

\section{Paparan hasil Kemampuan pemecahan masalah matematis bermuatan HOTS ditinjau dari gaya belajar auditorial}

Kemampuan pemecahan masalah siswa dalam menyelesaikan masalah matematis bermuatan HOTS berdasarkan gaya belajar auditorial dipilih secara random dengan inisial nama (SA). Berdasarkan hasil jawaban, SA mampu menyelesaikan semua soal tes uraian dengan baik, hanya saja ada satu soal yang SA mampu hanya sampai memahami soal. Hasil jawaban SA untuk soal C4 dapat dilihat pada Gambar 4.

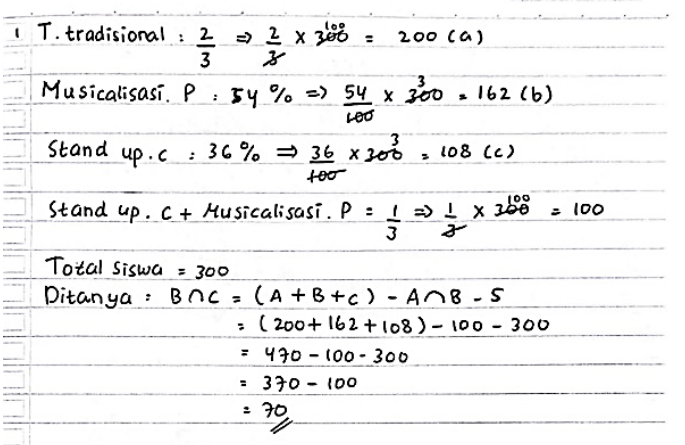

Gambar 4. Hasil jawaban SA pada soal C4.

Asapun hasil wawancara Peneliti (P) dengan SA adalah sebagai berikut.

$\mathrm{P}$ : Pada soal C4 informasi apa saja yang diketahui?"

SA : "Diketahui total siswa yang mengikuti pentas seni adalah 300 siswa. Siswa yang memilih menampilkan tarian tradisional ada $2 / 3$, siswa yang memilih menampilkan musikalisasi puisi ada 54\%, siswa yang memilih menampilkan stand up comedy ada $36 \%$, siswa yang memilih menampilkan stand up comedy dan musikalisasi puisi ada $1 / 3$ ".

P : "Bagaimana langkah-langkah kamu dalam menyelesaikan masalah ini?"

SA : "Hmmm...Pertama dimisalkan terlebih dahulu untuk seluruh 


$$
\begin{array}{ll} 
& \text { siswa yang mengikuti pentas } \\
& \text { seni dimisalkan dengan S, } \\
\text { tarian tradisional dimisalkan A, } \\
\text { musikalisasi puisi dimisalkan } \\
\text { B, stand up comedy dimisalkan } \\
\text { C dan untuk siswa yang } \\
\text { menampilkan musikalisasi } \\
\text { puisi dan tarian tradisional } \\
\text { dimisalkan }(A \cap B) . \text { Hmmm.... } \\
\text { Kemudian untuk menentukan } \\
\text { banyaknya siswa yang memilih } \\
\text { menampilkan musikalisasi } \\
\text { puisi dan stand up comedy } \\
\text { dimisalkan dengan }(B \cap C) \text { ". } \\
\text { "Lalu bagaimana langkah } \\
\text { selanjutnya?" } \quad \text { "aaaaa...Maka }(B \cap C)= \\
\text { SA } A+B+C)-A \cap B-S=200 \\
+162+108-100-300= \\
\\
370-100=70 . \text { Jadi banyak- } \\
\text { nya siswa yang memilih } \\
\text { menampilkan musikalisasi } \\
\text { puisi dan stand up comedy } \\
\text { adalah } 70 \text { siswa." }
\end{array}
$$

Berdasarkan hasil wawancara pada soal C4 SA mampu memenuhi indikator pemecahan masalah yaitu memahami masalah, membuat rencana pemecahan masalah, menyelesaikan masalah dan tidak mampu dalam memeriksa kembali hasil jawaban. Hal ini ditunjukkan dari hasil jawaban dan wawancara SA yang masih belum baik dalam menyelesaikan dan menjelaskan pemecahan masalah pada soal $\mathrm{C} 4$.

$\mathrm{P} \quad$ : Selanjutnya informasi apa yang kamu dapatkan dari soal C5?"

SA : "Informasi yang saya peroleh dari soal C5, keliling dari lahan berkebun adalah 16 meter dan lebarnya 2 meter lebih kecil dari panjangnya. Untuk lahan bermain berukuran 3 kali lebih besar dari lahan berkebun."
P : "Bagaimana langkah kamu menyelesaikan masalah C5?”

SA : "Langkah pertama, dimisalkan untuk panjang adalah $x$ dan lebar lahan berkebun adalah $(x-2)$ meter. Untuk lahan bermain panjangnya $3 x$ dan lebarnya $L=(3 x-6)$ meter."

$\mathrm{P}$ : "Kenapa kamu bisa menyimpulkan seperti itu?"

SA : "apaya ya hmmm... Karena disoal diketahui lebarnya 2 meter lebih kecil dari panjangnya, sehingga untuk panjangnya $x$ dan lebarnya $(x-2)$. Kalau untuk lahan bermain di jelaskan ukurannya 3 kali lebih besar dari lahan berkebun, maka untuk panjang dan lebarnya pun dikalikan dengan 3."

P : "Oke, bagaimana langkah selanjutnya?"

SA : "Selanjutnya untuk mendapatkan nilai $x$, kita subsitusikan ke rumus keliling lahan berkebun yaitu $K=$ 2 panjang +2 lebar sehingga $16=2 x+2(x-2)) \quad \rightarrow 16=$ $2 x+2 x-4, \quad 16=4 x-4$. Kemudian jumlahkan kedua sisi dengan $4,16+4=4 x-$ $4+4 \rightarrow 20=4 x$, maka nilai $x$ adalah $\frac{20}{4}=5 \mathrm{~m}$. Sehingga telah didapatkan panjang dari lahan berkebun adalah $5 \mathrm{~m}$. Kemudian untuk lebar lahan berkebun adalah $l=5-2=$ $3 \mathrm{~m}$."

P : "Lalu bagaiman dengan lahan bermain?"

SA : "hmmm....untuk lahan bermain, kita langsung subtitusikan saja ke dalam persamaan yaitu $3 x=3(5)=$ $15 \mathrm{~m}$ dan untuk lebarnya adalah $l=3(x-2)=3 x-6=$ 
DOI: https://doi.org/10.24127/ajpm.v10i3.3743

$$
\begin{aligned}
& 3(5)-6=15-6=9 \mathrm{~m} . \text { Maka } \\
& \text { akan di dapat luas lahan } \\
& \text { bermain adalah } L=p \times l= \\
& 15 \times 9=135 \mathrm{~m}^{2} \text {. Sehingga } \\
& \text { untuk luas lahan bermain } \\
& \text { adalah } 135 \mathrm{~m}^{2} \text { bukan } 124 \mathrm{~m}^{2} .
\end{aligned}
$$

Berdasarkan hasil wawancara pada soal C5 SA mampu memenuhi semua indikator pemecahan masalah yaitu memahami masalah, menyusun rencana pemecahan masalah dalam pemecahan masalah, dan memeriksa kembali hasil jawaban. Hal ini ditunjukkan dari hasil jawaban dan wawancara SA yang dapat menjelaskan penyelesaian masalah dengan baik.

P : "Selanjutnya Informasi apa yang kamu dapatkan dari soal C6?"

SA : "Informasi yang saya peroleh dari soal C6, panjang tiang masjid $=x \mathrm{~m}$, lebar tiang masjid $=(x-2) m$, tinggi tiang masjid $=(x+3) m . "$

$\mathrm{P} \quad$ : "Bagaimana langkah kamu dalam menyelesaikan masalah ini?"

SA : "Pertama untuk dapat mengetahui panjang besi, kita subtitusikan panjang, lebar dan tinggi tiang masjid ke rumus keliling yaitu $K=4 p+4 l+4 t$. Sehingga $K=4(x)+4(x-2)+$ $4(x+3)$ kemudian dijumlahkan, $\quad K=4 x+4 x-8+4 x+$ $12=12 x+4$. Maka panjang besi adalah $K=12 x+4$."

P : "Lalu selanjutnya?"

SA : "selanjutnya, kita buat pertidaksamaannya yaitu $12 x+4 \leq 46$ m. Kurangkan kedua ruas dengan 4 maka akan di dapat $12 x+4-4 \leq$ $46-4 \rightarrow 12 x \leq 42$, sehingga nilai $x$ nya, sehingga $x=\frac{42}{12}=$
3,5. Kemudian subtitusikan nilai $x$ ke dalam persamaan lebar dan tingginya, maka $l=x-2=3,5-2=1,5 \mathrm{~m}$ dan $t=x+3=3,5+3=$ $6,5 \mathrm{~m}$. Jadi ukuran maksimum balok adalah $(3,5 m \times 1,5 m \times$ 6,5).”

Berdasarkan hasil wawancara pada soal C6 SA mampu memenuhi dengan baik indikator pemecahan masalah yaitu memahami masalah, menyusun rencana pemecahan masalah dalam pemecahan masalah, dan memeriksa kembali hasil jawaban. Hal ini ditunjukkan dari hasil jawaban dan wawancara SA yang dapat menjelaskan penyelesaian masalah dengan baik. Namun walaupun sudah cukup baik dalam menyelesaikan masalah, SA masih kurang baik dalam menjelaskan penyelesaian masalah pada soal $\mathrm{C} 4, \mathrm{C} 5$, dan C6 pada tahap wawancara.

Hal ini sesuai dengan pendapat (Aprianti et al., 2020) bahwa gaya belajar auditorial hanya mampu dalam memahami masalah. Serta dalam penelitian (Purbaningrum, 2017) kemampuan berpikir tingkat tinggi dalam pemecahan masalah gaya belajar kinestetik masih tergolong sangat rendah $(31,82 \%)$

\section{Paparan hasil Kemampuan pemecahan masalah matematis bermuatan HOTS ditinjau dari gaya belajar kinestetik}

Kemampuan pemecahan masalah siswa dalam menyelesaikan masalah matematis bermuatan HOTS berdasarkan gaya belajar kinestetik dipilih secara random dengan inisial nama (MP). berdasarkan hasil jawaban MP mampu menyelesaikan semua soal tes uraian dengan baik. Di bawah ini merupakan hasil wawancara Peneliti (P) dengan MP. 
P : "Pada soal C4 informasi apa saja yang diketahui?"

MP : "Informasi yang saya dapatkan, suatu sekolah mengadakan acara pentas seni yang diikuti oleh 300 siswa. Pentas seni yang diadakan berupa tarian tradisional, stand up comedy, musikalisasi puisi. $2 / 3$ siswa menampilkan tarian tradisional, $54 \%$ siswa menampilkan musikalisasi puisi, 36\% siswa menampilkan stand up comedy, $1 / 3$ menampilkan musikalisasi puisi dan tarian tradisional".

P : "Lalu bagaimana langkahlangkah kamu dalam menyelesaikan masalah ini?"

MP : "Langkah pertama saya misalkan terlebih dahulu untuk seluruh siswa yang mengikuti pentas seni saya misalkan dengan $\mathrm{S}$, tarian tradisional saya misalkan A, musikalisasi puisi saya misalkan $B$, stand up comedy saya misalkan $\mathrm{C}$ dan untuk siswa yang menampilkan musikalisasi puisi dan tarian tradisional saya misalkan $(A \cap B) . "$

$\mathrm{P} \quad$ : "Setelah itu?"

MP : "Kemudian untuk menentukan banyaknya siswa yang memilih menampilkan musikalisasi puisi dan stand up comedy dimisalkan dengan $(B \cap C)$ yaitu dengan menambahkan siswa yang memilih A,B,C kemudian dikurangkan dengan siswa yang memilih $A \cap B$ dan banyaknya seluruh siswa yang mengikuti pentas seni. Sehingga diperoleh $300+$ $162+108-100-300=70$. Maka dari hasil tersebut dapat diketahui banyaknya siswa yang memilih menampilkan musikalisasi puisi dan stand up comedy adalah 70 siswa."

Berdasarkan hasil wawancara pada soal C4 MP mampu memenuhi semua indikator pemecahan masalah yaitu memahami masalah, menyusun rencana pemecahan masalah dalam pemecahan masalah, dan memeriksa kembali hasil jawaban. Hal ini ditunjukkan dari hasil jawaban dan wawancara MP yang dapat menjelaskan penyelesaian masalah dengan baik.

P : "Selanjutnya informasi apa yang kamu dapatkan dari soal C5?"

MP : "Informasi yang saya peroleh dari soal C5, lahan berkebun memiliki keliling 16 meter dengan lebar 2 meter lebih kecil dari panjangnya. Untuk lahan bermain berukuran 3 kali lebih besar dari lahan berkebun."

P : "Bagaimana langkah kamu dalam menyelesaikan masalah ini?"

MP : "langkah pertama, kita dapat misalkan untuk panjang adalah $x$ dan lebar lahan berkebun adalah $(x-2)$ meter. Maka kita dapatkan nilai $x$ dari persamaan keliling lahan berkebun adalah $K=$ 2 panjang +2 lebar sehingga $16=2 x+2(x-2)) \quad$ maka $16=2 x+2 x-4, \quad 16=4 x-$ 4. Kemudian kita hilangkan angka $-4 \quad$ dengan menjumlahkan 4 pada ke dua sisi $16+4=4 x-4+4$ akan didapatkan $20=4 x$, maka nilai $x$ adalah $\frac{20}{4}=5 \mathrm{~m}$."

$\mathrm{P} \quad$ : "Kemudian?" 
DOI: https://doi.org/10.24127/ajpm.v10i3.3743

MP : "Sehingga telah didapatkan panjang dari lahan berkebun adalah $5 \mathrm{~m}$. Maka untuk lebar lahan berkebun adalah $L=p-2=5-2=3 \mathrm{~m}$.

$\mathrm{P}$ : "Lalu bagaiman dengan lahan bermain?"

MP : "Untuk lahan bermain, diketahui pada soal bahwa lahan bermain berukuran 3 kali lebih besar dari lahan berkebun, sehingga untuk panjang dan lebarnya pun 3 kali lebih besar dari lahan berkebun. Sehingga untuk panjang lahan bermain adalah $3 x=3(5)=15 \mathrm{~m}$ dan untuk lebarnya adalah $3(x-2)=$ $3 x-6=3(5)-6=15-6=$ $9 \mathrm{~m}$. Maka akan di dapat luas lahan bermain adalah $L=p \times$ $l=15 \times 9=135 \mathrm{~m}^{2}$. Sehingga untuk luas lahan bermain adalah $135 \mathrm{~m}^{2}$ bukan $124 \mathrm{~m}^{2}$."

Berdasarkan hasil wawancara pada soal C4 dan C5 MP mampu memenuhi semua indikator pemecahan masalah yaitu memahami masalah, menyusun rencana pemecahan masalah dalam pemecahan masalah, dan memeriksa kembali hasil jawaban. Hal ini ditunjukkan dari hasil jawaban dan wawancara MP yang dapat menjelaskan penyelesaian masalah dengan baik.

P : "Selanjutnya informasi apa yang kamu dapatkan dari soal C6?"

MP : "Informasi yang saya peroleh dari soal C6, panjang tiang masjid $=x \mathrm{~m}$, lebar tiang masjid $=(x-2) m$, tinggi tiang masjid $=(x+3) m . "$

$\mathrm{P} \quad$ : "Bagaimana langkahmu dalam menyelesaikan masalah ini?"

MP : "langkah pertama, kita dapat membuat persamaan dengan menggunakan rumus keliling balok untuk mengetahui panjang besi yaitu $K=4 p+$ $4 l+4 t$. Kemudian kita substitusikan panjang, lebar dan tingginya ke dalam rumus, maka $K=4(x)+4(x-2)+$ $4(x+3)$ dan akan kita dapatkan bentuk persamaannya adalah $K=4 x+4 x-8+4 x+$ $12=12 x+4$. Maka panjang besi adalah $K=12 x+4$."

$\mathrm{P} \quad$ : "Kemudian?"

MP : "Kemudian untuk langkah selanjutnya, di dalam soal dikatakan jika panjang besi yang dipakai semuanya kurang dari $46 \mathrm{~m}$. maka akan kita buat pertidaksamaannya adalah $12 x+4 \leq 46 \mathrm{~m}$. selanjutnya kita selesaikan pertidaksamaan tersebut untuk mendapatkan nilai $x$ nya. Pertama, kita kurangkan kedua ruas dengan 4 maka akan di dapat $12 x+4-$ $4 \leq 46-4 \rightarrow 12 x \leq 42$. Kedua kita bagi kedua ruas dengan 12 untuk mengetahui nilai $x$ nya, sehingga $x=\frac{42}{12}=3,5$.

P : "Selanjutnya?"

MP : "Langkah selanjutnya, kita dapat subtitusikan nilai $x$ ke dalam persamaan lebar dan tingginya, sehingga di dapat lebarnya adalah $x-2=3,5-$ $2=1,5 \mathrm{~m}$ dan untuk tingginya adalah $\quad x+3=3,5+3=$ $7,5 \mathrm{~m}$. Maka untuk ukuran maksimum balok adalah $(3,5 m \times 1,5 m \times 7,5)$

Sedangkan untuk hasil dari jawaban MP terhadap soal C6 dapat dilihat pada Gambar 5. 
DOI: https://doi.org/10.24127/ajpm.v10i3.3743

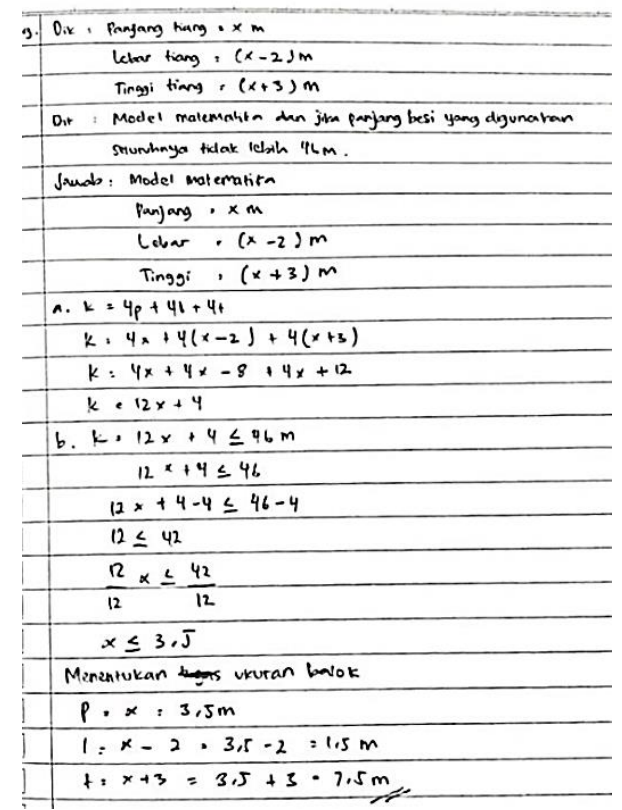

Gambar 5. Hasil jawaban soal C6 MP

Berdasarkan hasil wawancara pada soal C6 MP mampu memenuhi indikator dalam pemecahan masalah yaitu memahami masalah dan menyusun rencana pemecahan masalah. Hal ini ditunjukkan dari reaksi tanggapan dan wawancara MP yang dapat menerangkan penyelesaian masalah dengan benar. Namun untuk C6 MP masih belum mampu untuk menyelesaikan masalah, hal ini terbukti dari reaksi tanggapan MP yang masih kurang teliti dalam menghitung yang menyebabkan salah dibagian akhir.

Hal ini sesuai dengan pendapat (Imamuddin et al., 2019) bahwa siswa yang memiliki gaya belajar kinestetik belum mampu untuk menyelesaikan masalah dan memeriksa kembali jawaban. Gambar 5 adalah reaksi tanggapan MP pada soal C6.

Untuk mendapatkan hasil yang maksimal dalam menyelesaikan masalah matematika bermuatan HOTS, harus dilakukan dengan langkahlangkah pemecahan masalah matematis secara sistematis yang baik (Umrana et al., 2019). Hal ini terbukti dari hasil penelitian dilapangan bahwa ketiga subjek yang memiliki gaya belajar berbeda memecahkan masalah dengan menggunakan tahapan pada indikator kemampuan pemecahan masalah. Namun jika dilihat dari pandangan kuantitatif subjek masih belum terpenuhi dengan baik, karena masih kurang dalam pemahaman materi dan banyak terjadi kekeliruan dalam perhitungan.

\section{KESIMPULAN DAN SARAN}

Berdasarkan hasil analisis dan pembahasan pada penelitian ini, dapat disimpulkan Kemampuan pemecahan masalah matematis bermuatan HOTS pada siswa yang memiliki gaya belajar visual mampu memenuhi dengan baik semua indikator pemecahan masalah pada soal C4, C5 dan C6. Kemampuan pemecahan masalah pada siswa dengan gaya belajar auditorial mampu memenuhi dengan baik semua indicator pemecahan masalah pada soal C5 dan C6. Siswa auditorial masih kesulitan dalam merencanakan penyelesaian masalah pada soal C4. Kemampuan pemecahan masalah matematis bermuatan HOTS pada siswa dengan gaya belajar kinestetik mampu dengan baik memenuhi semua indicator pemecahan masalah pada soal C4 dan C5. Siswa kinestetik masih mengalami kesulitan dalam menyelesaikan masalah soal C6.

Berdasarkan sesuai hasil penelitian disarankan dalam pembelajaran matematika untuk meningkatkan kemampuan pemecahan masalah matematis bermuatan HOTS, sebaiknya mengguunakan gaya belajar visual sehingga dapat memaksimalkan dalam pemecahan masalah matematis.

\section{DAFTAR PUSTAKA}

Ahmad, M. (2017). P Engembangan P Erangkat $\mathrm{P}$ Embelajaran $\mathrm{M}$ 
DOI: https://doi.org/10.24127/ajpm.v10i3.3743

Atematika R Ealistik Untuk $\mathrm{M}$ Embelajarkan $\mathrm{K}$ Emampuan $\mathrm{P}$ Emecahan M Asalah M Atematika $S$ Iswa Smp D Evelopment of $\mathrm{R}$ Ealistic $\mathrm{M}$ Athematics L Earning D Evices To $\mathrm{T}$ Each $\mathrm{S}$ Tudent. Jurnal "Mosharafa," 6(September), 373-384.

Akbar, P., Hamid, A., Bernard, M., \& Sugandi, A. I. (2017). Analisis Kemampuan Pemecahan Masalah Dan Disposisi Matematik Siswa Kelas Xi Sma Putra Juang Dalam Materi Peluang. Jurnal Cendekia: Jurnal Pendidikan Matematika, 2(1), 144-153. https://doi.org/10.31004/cendekia. v2i1.62

Amalia, D., \& Hadi, W. (2020). Analisis Kesalahan Siswa Dalam Menyelesaikan Soal Hots Berdasarkan Kemampuan Penalaran Matematis. Transformasi : Jurnal Pendidikan Matematika Dan Matematika, 4(1), 219-236. https://doi.org/10.36526/tr.v4i1.90 4

Aprianti, B. D., Sucipto, L., Riska, K., \& Kurniawati, A. (2020). Analisis kemampuan pemecahan masalah matematika kelas viii berdasarkan gaya belajar siswa. Paedogoria: Jurnal Kajian, Penelitian, Dan Pengembangan Kependidikan, 11(3), 289-296. http;//journal.ummat.ac.id/index.p hp/paedagoria

Harahap, E. R., \& Surya, E. (2017). Kemampuan Pemecahan Masalah Matematis Siswa Kelas VII Dalam Menyelesaikan Persamaan Linear Satu Variabel. Jurnal Edumatica, 07.

Ilmi, M. B., \& Rosyidi, A. H. (2016). Profil Pemecaham Masalah
Matematika Siswa SMP Kelas VIII Ditinjau dari Tingkat Kecerdasan Emosional dan Kemampuan Matematika. Jurnal Ilmiah Pendidikan Matematika, 1(5), 21-29.

Imamuddin, M., Rusdi, Isnaniah, \& Audina, M. (2019). Kemampuan Pemecahan Masalah Matematika Siswa Berdasarkan Gaya Belajar. Al-Khwarizmi: Jurnal Pendidikan Matematika Dan Ilmu Pengetahuan Alam, 8(5), 55.

Mangwende, E., \& Maharaj, A. (2019). Barriers to Mathematics Teachers' Use of Their Knowledge of Students' Learning Styles in Mathematics Teaching: A Case of Secondary Schools in Zimbabwe. EURASIA Journal of Mathematics, Science and Technology Education, 16(1), 115.

https://doi.org/10.29333/ejmste/10 9198

Mariam, S., Rohaeti, E. E., \& Sariningsih, R. (2018). Analisis Kemampuan Pemecahan Masalah Matematis Siswa Madrasah Aliyah pada Materi Pola Bilangan. Journal on Education, 1(2), 156-162.

OECD. (2019). Programme for international student assessment (PISA) results from PISA 2018. Oecd, 1-10. https://www.oecd.org/pisa/publica tions/PISA2018_CN_IDN.pdf

Purbaningrum, K. A. (2017). Kemampuan Berpikir Tingkat Tinggi Siswa Smp Dalam Pemecahan Masalah Matematika Ditinjau Dari Gaya Belajar. Jurnal Penelitian Dan Pembelajaran Matematika, 10(2), 40-49. https://doi.org/10.30870/jppm.v10 
DOI: https://doi.org/10.24127/ajpm.v10i3.3743

\section{i2.2029}

Putra, H. D., Putri, W. A. S., Fitriana, U., \& Andayani, F. (2018). Kemampuan Pemecahan Masalah Matematis dan Self-Confidence Siswa. Supremum Journal of Mathematics Education, 2(1), 6070.

Rambe, A. Y. F., \& Afri, D. L. (2020). Analisis kemampuan pemecahan masalah matematis siswa dalam menyelesaikan soal materi barisan dan deret. AXIOM: Jurnal Pendidikan Dan Matematika, 09(2), 175-187.

Richardo, R., Retno, D., \& Saputro, S. (2014). Matematika Divergen Ditinjau Dari Gaya Belajar Siswa ( Studi Pada Siswa Kelas IX MTS Negeri Plupuh Kabupaten Sragen Semester Gasal Tahun Pelajaran 2013 / 2014 ). Jurnal Elektronik Pembelajaran Matematika, 2(2), 141-151.

Saputri, A. E., \& Hadi, W. (2021). Pengembangan E-book Bermuatan High Order Thinking Skill (HOTS). 10(2), 1008-1021.

Setyadi, D., Masi, L., Salim, S., \& Kadir, K. (2020). Analisis Kemampuan Pemecahan Masalah Matematis Siswa SMP Ditinjau Dari Perbedaan Gaya Belajar. Jurnal Amal Pendidikan, 1(1), 63-69.

http://ojs.uho.ac.id/index.php/jape nd/article/view/11684

Solihah, S., Mulyani, L. S., \& Ardiana, C. (2020). Analisis Gaya Belajar Siswa Berdasarkan Visual, Auditori, Kinestetik Pada Mata Pelajaran Biologi MAN 1 Garut. Gunahumas Jurnal Kehumasan, 3(1), 1-12.

Suratmi, S., \& Purnami, A. S. (2017). Pengaruh Strategi Metakognitif Terhadap Kemampuan
Pemecahan Masalah Matematika Ditinjau Dari Persepsi Siswa Terhadap Pelajaran Matematika. UNION: Jurnal Ilmiah Pendidikan Matematika, 5(2), 183-194.

https://doi.org/10.30738/.v5i2.124 1

Umrana, Cahyono, E., \& Sudia, M. (2019). Analisis Kemampuan Pemecahan Masalah Matematis Ditinjau dari Gaya Belajar Siswa. Jurnal Pembelajaran Berpikir Matematika, 4(1), 67-76.

Wahyuni, Y. (2017). Indentifikasi Gaya Belajar (Visual, Auditorial, Kinestetik) Mahasiswa Pendidikan Matematika Universitas Bung Hatta. JPPM, 10(2).

Yusuf, M., Amin, M., Tarbiyah, F., Uin, K., \& Makassar, A. (2016). Pengaruh Mind Map dan Gaya Belajar Terhadap Hasil Belajar Matematika Siswa. Jurnal Keguruan Dan Ilmu Tarbiyah. https://ejournal.radenintan.ac.id/in dex.php/tadris 